\title{
Civil Rights and Political Participation in Ancien Régime Europe
}

\section{W. Blockmans}

For citation: Blockmans W. Civil Rights and Political Participation in Ancien Régime Europe. Vestnik of Saint Petersburg University. History, 2020, vol. 65, issue 3, pp. 842-864.

https://doi.org/10.21638/11701/spbu02.2020.309

\begin{abstract}
After the Second World War, a wave of euphoria fostered an international consensus that led to the creation of the Universal Declaration of Human Rights and the European Treaty for Human Rights, and institutions safeguarding their application. In the early $21^{\text {st }}$ century, however, these great ideals and even parliamentary democracy appear to be open to various forms of manipulation tending to the restriction of its own constitutional rights and functions. This paper retraces the long-term genesis of these concepts which emerged in the course of a centuries-long development that is uniquely European. A constant tension can be observed between the difficult formulation of fundamental rights of subjects, originally on a local and regional basis, and the effectiveness of the institutions created to control governments. The growth of cities, which acquired various levels of autonomy and autarchy, was fundamental to make it possible that immunities and particular privileges similar to those of clerics and aristocrats were extended to the new communities. The periods of urban growth, and the density of cities within particular territories, determined which balance of powers was stabilised. The earliest and most intense wave of urbanisation, in North and Central Italy from the $10^{\text {th }}$ to the $13^{\text {th }}$ century, brought civil rights and privileges for local communes, but also domination of the largest cities as they absorbed or eliminated all potentially countervailing powers. In other regions, various balances were attained between the prevailing seigneurial interests and those of urban communities.
\end{abstract}

Keywords: urbanisation, commercialisation, privileges, representation, oligarchisation.

Wim Blockmans - Doctor in History, Professor Emeritus, University of Leiden, 16, Doelensteeg, VL Leiden, 2311, The Netherlands; wimblockmans7@gmail.com

Вим Блокманс - д-р ист. наук, почетный проф., Лейденский университет, Нидерланды, 2311, Лейден, ул. Дуленстег, 16; wimblockmans7@gmail.com

() Санкт-Петербургский государственный университет, 2020 


\section{Гражданские права и участие населения в политической жизни Европы старого порядка}

\section{В. Блокманс}

Для цитирования: Blockmans W. Civil Rights and Political Participation in Ancien Régime Europe // Вестник Санкт-Петербургского университета. История. 2020. Т. 65. Вып. 3. С. 842-864. https://doi.org/10.21638/11701/spbu02.2020.309

После окончания Второй мировой войны всплеск эйфории способствовал международного консенсусу, в рамках которого были выработаны Всеобщая декларация прав человека и Европейская конвенция о защите прав человека и основных свобод, а также институтов, их защищающих. Однако в начале XXI в. провозглашенные великие идеалы и даже парламентская демократия оказались беззащитны перед различными государственными манипуляциями, стремящимися к ограничению конституционных прав и обязанностей. Статья обращается к моменту зарождения и развития концепций, которые формировались в течение многовекового развития Европы. Наблюдалась постоянная напряженность между сложной формулировкой фундаментальных прав субъектов, первоначально на локальной и региональной основе, и эффективностью институтов, созданных для контроля над органами власти. Рост городов, получивших различные уровни автономии, был фундаментом для того, чтобы иммунитеты и особые привилегии, подобные корпоративным правам священнослужителей и аристократов, распространились и на новые общины. Периоды возникновения городов на конкретных территориях определяли соотношение сил. Самая ранняя и интенсивная волна урбанизации в Северной и Центральной Италии с X по XIII в. принесла не только гражданские права и привилегии местным общинам, но и господство крупнейших городов вследствие ликвидации всех потенциально равных полномочий. В других регионах было достигнуто равное соотношение между доминирующими интересами городского населения и интересами городских общин.

Ключевые слова: урбанизация, коммерциализация, привилегии, представительства, олигархизация.

Citizens' fundamental rights, and the institutional warrants to uphold them, have been elaborated on the level of states in the course of the last nine centuries. These attainments originally constituted a uniquely European phenomenon which did not emerge in China or in the Mughal and Ottoman empires, though the Asian civilisations had reached a high development at an earlier stage, and China maintained a level of growth and living standard comparable to that in Europe until around $1750^{1}$. Local government was generally subservient to the imperial administration, while in Western Europe it acquired a level of autonomy that allowed bargaining with the central authorities ${ }^{2}$. It was not the study of ancient philosophy, civic humanism, or the Enlightenment philosophy which brought about the innovation of political thought, although the learned authors might have formulated and systematised the claims and expectations that under specific circumstances had come "in the air" already. Pragmatic arrangements and partial concessions stabilised into what, in hindsight, appears to have been a major transition.

${ }^{1}$ Maddison A. Contours of the World Economy, 1-2030 AD. Oxford, 2007. P. 158.

2 Prak M. Citizens without Nations. Urban Citizenship in Europe and the World c. 1000-1789. Cambridge, 2018. P. 271-273. 
Real breakthroughs came as the outcome of extreme economic crises and tensions within the political system that in turn reflected major social changes ${ }^{3}$. Only rarely did grand ideological programmes steer revolutionary changes in the social relations and the political system. In general, protests against concrete issues might coagulate into broadening movements and obtain partial concessions. However, established power elites never voluntarily or easily give up their privileges. As long as they remain united, they hold the supremacy of the means of power which they self-evidently use to maintain their position. Fundamental rights therefore need to be fought for in bloody conflicts, upheavals, revolts, and revolutions. Mass mobilisations of the powerless are always exceptional features triggered by extreme conditions; diffusion, weak organisation and inferior military means constitute major challenges in the confrontation between the masses and the elites' institutionalised power. Moreover, time tends to dissolve the upheaval, especially if the elite is prepared to make limited concessions, and then eagerly neglects them as soon as the opposition loses its mobilisation and coherence ${ }^{4}$.

Major steps in the elaboration of rights protecting subjects against the rulers' natural propensity to abuse their power were therefore set in the course of large-scale social and political conflicts which entailed mass mobilisation and mostly violent clashes. In 1581, the Estates General of the Low Countries declared King Philip II of Spain deposed as lord because he had systematically violated all kinds of rights, laws, customs and privileges. At that moment, uprisings, collective violence and military actions had been going on for fifteen years, and criticism of the government had been widely disseminated in tens of thousands printed pamphlets. The text of the "Act of Abjuration" contains a long enumeration of all the king's misdoings and lists a great variety of individual and particular measures to correct infringements. The deposition of Europe's mightiest ruler by a representative assembly was motivated by extensive references to natural, feudal, and customary law, chartered privileges granted to local communities, and historical precedents. Though key actors were informed by the writings and preaching of mainly Calvinist thinkers, their argument was still a pragmatic conglomerate rather than an overarching political theory. A ruler's inauguration oath intrinsically obliged him to maintain the law of each of his territories. The motivation was purely political in contrast to the criminal cases carried by the House of Lords which led to the deposition and execution of two kings of England in the $14^{\text {th }}$ century, and Charles I - in 1649. After eighty years of open warfare, and the Spanish empire's huge military effort, the hazards of battlefields determined which Netherlandish territories would remain under Spanish authority, and which others could not be subdued ${ }^{5}$.

The next step in the development of control by the representative institutions was the dramatically unfortunate deposition of Emperor Ferdinand II by the Bohemian Estates in 1619. Further came the ongoing conflicts in England between Parliament and the autocratic Stuart kings. In 1628, both Houses of Parliament agreed on a Petition of Right to

3 Skocpol T. States \& Social Revolutions. A Comparative Analysis of France, Russia, \& China. Cambridge, 1979. P. 3-43.

4 Mann M. The sources of social power. Vol. I A history of power from the beginning to A. D. 1760 . Cambridge, 1986. P.18-32; Popitz H. Phenomena of Power. Authority, Domination, and Violence. New York, 2017.

5 Van Gelderen M.: 1) The Political Thought of the Dutch Revolt 1555-1590. Cambridge, 1992. P. 146162; 2) The Dutch Revolt. Cambridge, 1993; Hart M. ' $t$ The Dutch Wars of Independence: Warfare and Commerce in the Netherlands 1570-1680. London; New York, 2014. P. 1-20. 
oppose the ongoing abuses committed by King Charles I. In the beginning the document confirmed Magna Carta and the laws granted in the 1350s by Edward III. It enumerated flagrant violations of civil rights and abuses of martial law, and then formulated concrete restrictions of royal power by the requirement of a judicial verdict for imprisonment and expropriation, and Parliament's consent for taxation ${ }^{6}$. The king agreed with these stipulations but violated them within a few months. Nevertheless, they became the basis of the Bill of Rights granted by William and Mary in 1689, after the so-called Glorious Revolution.

This act, as well as the Act of Abjuration of 1581, inspired the American Declaration of Independence of 1776 . Truly systematic and forward-looking constitutional texts emerged only in 1789 in America, and in 1795 - in The Netherlands ${ }^{7}$. The French Revolution produced the Déclaration des droits de l'homme et du citoyen in 1789, 1793, and 1795. The latter's universal ambition in its turn inspired the Universal Declaration of $\mathrm{Hu}-$ man Rights issued by the United Nations in 1948, and the European Treaty for Human Rights in 1949 signed by 47 states, both in reaction to the horrors of the Second World War. Both treaties were complemented by a long list of over two-hundred conventions aimed at the protection of specific rights, such as the Charter of Fundamental Rights of the European Union, the European Convention on Human Rights and the Framework Convention for the Protection of National Minorities. Since their conclusion only some states have ratified them, and their implementation has become ever more problematic in the last decade. Nowadays, several EU member states are systematically restricting or violating fundamental rights which formed the basis of European unification process. This evolution reminds us of the historical observation that governments tend to expand their competences to the detriment of parliamentary control; more concern is raised, however, by the fact that majorities in elected parliaments support these silent take-overs. Parliamentary democracy in the early $21^{\text {st }}$ century appears to be open to various forms of manipulation tending to the restriction of its own constitutional rights and functions. Therefore, the tension between the difficult formulation of fundamental rights of subjects, and the effectiveness of the institutions created to control governments deserves an analysis of its long-term genesis.

The state of the art. Research on representative institutions has a long tradition ${ }^{8}$. In the nineteenth century, newly created national states supported extensive publication programmes in order to present historical precedents of parliamentary representation as legitimation of their new status. Also, in recent times, newly erected democratic regimes as well as several regional authorities are undertaking a similar exercise ${ }^{9}$. The need to build

${ }^{6}$ Constitution Society. URL: www.constitution.org/eng/petright.htm (accessed: 21.04.2020).

7 Rowen H. H. The Union of Utrecht and the Articles of Confederation, the Batavian Constitution and the American Constitution, a double Parallel // Herrschaftsverträge, Wahlkapitulationen, Fundamentalgesetze / Hrsg. R. Vierhaus. Göttingen, 1977. S. 283.

8 See the lucid introductory remarks in: Bisson T.: 1) Assemblies and representation in Languedoc in the thirteenth century. Princeton, 1964. P. 1-16; 2) The Problem of Medieval Parliamentarism: A Review of Work published by the International Commission for the History of Representative and Parliamentary Institutions, 1936-2000 // Parliaments, Estates, Representation. 2001. Vol.21. P. 1-14; Guenée B. L'Occident aux XIVe et XVe siècles. Les Etats. Paris, 1971. P.302-308; general theories and visions have been discussed by Krüger K. Die Landständische Verfassung. Munich, 2010. S.51-86. - An extensive bibliography is to be found in: Hébert M. Parlementer. Assemblées représentatives et échange politique en Europe occidentale à la fin du Moyen Age. Paris, 2014. P.601-652.

9 Acta Curiarum Regni Aragonum / eds J. A. Sesma Muñoz, C. Laliena Corbera. Saragossa, 2006. URL: http.www.patrimonioculturaldearagon.es/coleccion-acta-curiarum-regni-aragonum (accessed: 
up legitimacy through historical precedents oriented research to the national specificity within the borders established after wars, which is still characteristic for such studies. The main tendency in historical research and teaching was purely teleological, providing a justification for the national states as they had been designed after major military conflicts, at conference tables, on the basis of the lines accidentally established in truces ${ }^{10}$. By referring to older examples, existing representative institutions suggest a continuity with centuries-old traditions even in their names, e.g. the (Roman) Senate.

Parliament, on the other hand, was a term derived from the medieval Latin "parlamentum", which refers to any type of formalised negotiation. "A notable assembly or 'parley', especially of king and barons, parlement was taken over as the name of the newly professional law-court which complaints to the king called into existence within the royal household"11. The designation of the high royal court as parlement was common to the French and the English court, which in the English case remained so until 1322. Parlements including two knights from each shire were summoned in particularly critical situations requiring political decisions, especially regarding the levy of new taxes. That was the case in 1265, 1275, 1290, and more regularly - from the mid-1290s onwards. The assemblies called parlement in England thus originally referred to judicial meetings, and were gradually used for political meetings, exclusively so from 1322 onwards ${ }^{12}$. Most names were derived from extended councils at court: Cortes, Reichstag, Rikstag, Landtag, Sejm, Dièta, Doema, House(s), Chamber(s), States (-General), Ständerat / Conseil des États (Switzerland).

The great diversity of regional traditions induced historians to limit themselves to descriptions of particular cases. The activity of the International Commission for the History of Parliamentary and Representative Institutions, created in 1936, produced an impressive amount of descriptive case-studies ${ }^{13}$, but no overall understanding of the necessary and sufficient conditions for the emergence of assemblies, their diversity, their impact, and their decline. Very few attempts have been made to offer overall interpretations, including the reasons for their absence from the highest developed regions in North and Central Italy ${ }^{14}$. Descriptions remained limited to national boundaries, and they overwhelmingly focused on constitutional frameworks ${ }^{15}$. Antonio Marongiu expanded his work on parliaments in Italy's peripheral regions with materials on some Western parliaments in the Middle Ages, applying a constitutional focus ${ }^{16}$. The most impressive enterprise to launch a truly comparative analysis came from outside the International Commission, name-

21.04.2020); Textos Jurídics Catalans. Vol.8. Barcelona, 1992. URL: http://justicia.gencat.cat/ca/departament/publicacions/col_leccions_actives/textos_juridics_catalans/ (accessed: 21.04.2020); Acta Curiarum Regni Sardiniae. Cagliari, 1991. 17 volumes published until 2020. URL: http://consiglio.regione.sardegna.it/ acta_curiarum/ (accessed: 21.04.2020); Cortes Portuguesas / Instituto Nacional de Investigação Científica. 11 vols. Lisbon, 1982-2018.

10 An example is: Marongiu A. L'Istituto Parlamentare in Italia dalle origini al 1500. Rome, 1949, commissioned by the Senate of the Italian Republic, after the defeat of the fascist dictatorial regime.

${ }_{11}$ Harding A. Medieval Law and the Foundations of the State. Oxford, 2002. P. 162-163.

12 Ibid. P. 174, 176.

13 Bisson T. The Problem of Medieval Parliamentarism. - Launched in 1981, the review "Parliaments, Estates and Representation" carries on the International Commission's tradition.

14 Hébert M. La voix du peuple. Une histoire des assemblées au Moyen Âge. Paris, 2018. P. 72.

15 Hébert M. Parlementer. Assemblées représentatives et échange politique en Europe occidentale à la fin du Moyen Age. Paris, 2014. P. 10-11.

16 Marongiu A. Medieval Parliaments. A comparative study. London, 1968. 
ly from the Société Jean Bodin pour l'Histoire Comparative des Institutions, which has a great track record on world-wide comparative study of institutions in various domains. Its scope covers all time periods and all continents, and contributions were presented to a congress in 1962 on the basis of a detailed questionnaire covering a wide range of aspects. The volumes on the European Ancien Régime offer the broadest information on the greatest number of regional cases addressing as much as possible the same issues. The daring synthetical conclusions had to cover too wide a range in time and space, which made it impossible to formulate a clear encompassing theory ${ }^{17}$. Just two compact books for educational purposes provide overviews of the whole, or just the central part of the Ancien Régime ${ }^{18}$. The author of one of those, Professor A. R. Myers, qualified the state of the art in 1975 as follows: "In the last forty years much research has been done on particular parliaments and on special aspects of their organization and role; but this is the first comprehensive study of their rise and progress as a phenomenon of Western Europe".

Orders and Estates. As the terminology referred to a great variety of specific historical institutions, most historical research on representative institutions is framed within the borders of modern states, and the very rare examples of comparative overviews find it difficult to offer more than the juxtaposition of different cases. The general idea of representation by Estates may be considered an empty truism because all societies in the Ancien Régime were characterised by the strictly hierarchical orders entrenched in distinct juridical and social categories. Members of the first two Estates enjoyed a privileged status in all respects: they owned by far the largest share of all wealth, controlled the means of production including the great majority of the labour force; and they shared the complementary dimensions of symbolic and physical power. As a matter of course, the most prominent members of the clergy and the aristocracy held political influence on a purely personal basis, because of their wealth and power. Their regular role in councils and at courts rested on mutual self-interest: rulers needed the support and expertise of the most educated and mightiest while the former profited from the opportunity to strengthen their own positions. Notwithstanding all rhetoric of "representing" or "being" the land, it was as private persons that aristocrats held a share of public power over large stretches of land and great numbers of people; that power was reproduced via the inheritance rules of their order and local traditions. The clergy operated in a similar system of specific rules in canon law, formally immune from lay power. Admission may have been favoured by aristocratic roots, but in principle, it rested on the observance of private rules. Accession to leading positions was in principle determined by election on the basis of merit. Both orders enjoyed privileges, aristocrats - by ascription (birth-right), the clergy — by admission. They ruled on the basis of customary law over their subjects living on their domains and in their lordships, whose sole masters and judges they were; the same applied to other members of their religious community or family. Together, clerics and aristocrats controlled by far the largest share of the means of power: its symbolic dimension, the means of production, the means of coercion.

The idea that the first two "Orders", or a selection from them in the "Estates", represented the land, or even, in Otto Brunner's famous expression, that "they were the land", was a convenient fiction to dissimulate the reality of bluntly serving their particular in-

17 Gouvernés et Gouvernants / Société Jean Bodin. Vols 3, 4. Brussels, 1965-1966.

18 Myers A.R. Parliaments and Estates in Europe to 1789. London, 1975; Graves M. A. R. The Parliaments of Early Modern Europe. London, 2001. 
terests ${ }^{19}$. A ruler selected the wealthiest and mightiest clerics and aristocrats within his territory because he needed their advice, information, and support. None of them really represented the clerical order as a whole since large categories such as the mendicant orders and the lower clergy were never consulted, and, in general, were the least propertied $^{20}$. Similarly, lesser members of the aristocracy, and especially the chivalry, were generally not invited, with the exception of the Kingdom of Aragon, Catalonia, Béarn, and some German territorial assemblies (Landtage) where they formed an Estate of their own. Neither were subjects on the domains asked for their opinion; they were not invited to empower their landlord to speak on their behalf, nor was he supposed to render an account of the decisions he had approved. Landlords ruled as patriarchal autocrats bound only by local customs and the Christian requirement to provide paternal care and protection. Even within a religious community, it was the bishop, abbot, or dean who held paternal authority, as the pater familias held it in an aristocratic family. On the other hand, English knights of the shire were elected and really represented not only the gentry, but also free peasants owning property of a determined value. Nobles often held land in several territories which could bind them to more than one lord and ruler; also, in a feudal aspect, the social order did not coincide with the political Estate. In many cases, noblemen held offices in cities and did represent these. The orders as a juridical category and a socially distinctive class did thus not coincide with the political Estate composed by some of their most prominent members whom the ruler selected at will, keeping in mind their superior wealth and power.

The claim that the great landlords spoke on behalf of the land and were "the land" was a fiction that helped to justify their domination over the common people ${ }^{21}$. In real life, the magnates enjoyed privileges and wealth as well as prestige. Members of the first two orders were generally distinguished by codes of life style, dress, attitude, social distancing and interaction, esteemed and respected in daily life. Common people acknowledged the political fiction of being represented as long as it was seen as convenient, in the awareness that there was no alternative because the elites controlled the means of power to impose their domination. The Church had deeply impregnated in the minds and souls a sense of transcendence of the established social order. Even the slightest opposition against privileges was considered outrageous and deemed an infringement of the godly order that needed to be punished in an exemplary way as lese-majesty, severely and publicly. It has to be acknowledged that petitions and presentations of grievances (gravamina), in an extreme case even passive resistance, were perceived as acceptable in so far as they pointed to infringements of the community's customary law. However, the sense of inevitability of the given social inequalities made most people passively undergo massive deprivation, suffering, and injustice ${ }^{22}$. Only extreme circumstances could motivate ordinary people to risk a revolt, and most of them ended in disasters.

19 Brunner O. Land und Herrschaft. Grundfragen der territorialen Verfassungsgeschichte Österreichs im Mittelalter. Brno, 1942. S. 473. - In support of this view: Hébert M. La voix du peuple. Une histoire des assemblées au Moyen Âge. Paris, 2018. P. 162-167.

20 Hébert M. Parlementer. P. 247-253.

${ }^{21}$ Stollberg-Rilinger B.: 1) Vormünder des Volkes? Konzepte landständischer Repräsentation in der Spätphase des Alten Reiches. Berlin, 1999. S.298-300; 2) Was heißt landständische Repräsentation? Überlegungen zur argumentativen Verwendung eines politischen Begriffs // Zeitsprünge. 2000. Bd.4. Hf. 1-2. S. $122-124$.

22 Moore B. Injustice. The Social Bases of Obedience and Revolt. London, 1978. P. 458-462, 489-501. 
Historians currently take historical fiction of representation for granted, by which they displayed a fundamental misunderstanding of the mechanisms of the patriarchal exercise of power. As none of the first two orders (in a modern political sense) represented anybody or anything else than the particular interests of their religious community or aristocratic family, I think that historical research needs to qualify the whole idea of "representation by Estates" as an ideological construction dissimulating the reality of power bases. Further on, in the political practice, the assemblies of the Ancien Régime were far from being modelled along the lines of the two "privileged Estates" and the "Third Estate". Practical arrangements show a huge variety of assemblies, in which the number of "Estates" mattered less than the variety of categories sharing bits of power who were absent or excluded: (arch-)bishops, abbots, deans and provosts, (high) nobles and lesser chivalry or gentlemen, cities and towns, communities of free peasants. They were grouped in various ways, in England not by Estate but by rank: high clergy and lords in the House of Lords, the gentry, citizens, and propertied commoners in the House of Commons. In 1769, an overview of the "sovereign" units in the German Empire listed ecclesiastical territories, principalities, imperial cities with a dependant territory, and sixteen "rural landscapes of free peasants (Landschaften)". 48 of these units did not have any form of representation, in 89 of them the assemblies consisted of four, three, or two Estates ${ }^{23}$. As there was no such thing as a general European model of assemblies, it makes no sense to qualify as an "anomaly" the fact that from 1538 onwards the king of Castile didn't summon the clergy and the aristocracy to the Cortes ${ }^{24}$.

Conditions for the emergence of popular representation. The most comprehensive and influential theory was formulated as long ago as 1931 by the German historian Otto Hintze $^{25}$. He identified what he saw as the conditions necessary for the unique emergence of representative government in western Europe, and nowhere else in the world - as an endogenous process. In his view, political and social life in the West was moulded by the twin systems of feudalism and the Christian Church. The high clergy, the only intellectuals controlling the chanceries of the emerging states, could impose limitations on lay authority by referring to general rules of Christian ethic. Germanic law, especially as it was formalised in feudalism, offered a second limitation to rule in its concept of reciprocal power relations. A ruler was always bound by mutual obligations of loyal counsel and (military) aid by his vassals, while he as the lord had to offer protection and material support. The lord could be held to respect certain moral obligations and standards, as vassals were entitled to withhold their assistance and eventually to break the bounds of loyalty if the lord violated the terms of their contract. The immunity of ecclesiastical institutions, the clergy and the inhabitants of lordships, and, at a later stage, also that of cities, formed the basis of subjective public rights of privileged social categories.

Western states did not grow into a unified empire but constituted weakly integrated parts of a loose global system which shared Christian values imposed by a universal and independent Church. The constant competition between feudal lords led to the elimination of weaker contenders and the formation of ever larger units. The growing states

${ }^{23}$ Krüger K. Die Landständische Verfassung. Munich, 2010. S.18-26.

${ }^{24}$ Fortea Pérez J. I. Las Cortes de Castilla y León bajo las Austrias. Valladolid, 2008. P. 369.

${ }^{25}$ Hintze O. Weltgeschichtliche Bedingungen der Representativverfassung // Historische Zeitschrift. 1931. Bd. 143. S. 1-47; reprinted in: Hintze O. Gesammelte Abhandlungen I. Staat und Verfassung. Göttingen, 1970. S. $120-139$. 
continued that competition, which required the steady intensification and rationalisation of their power systems. As the most successful competitors, the kings created and expanded their own judiciary system and fiscal administration. They sought the active support of citizens for the mobilisation of resources, and, eventually, against unruly noblemen. The ecclesiastical model of conciliar representation was easily transferred to secular circumstances. Hintze saw the extension of monarchical authority over the representative institutions as a necessary condition for the development of representation: in his view "municipal structures everywhere excluded representation by estates". On the other hand, unlimited feudalism tended to dissolve the emerging states. Representative institutions could only develop and last within centralising states.

In a complementary article, published a year earlier, Hintze had developed a typology of representative institutions based on the alleged dichotomy of bi- and tri-cameral systems. He linked the English and Polish bicameral parliaments to the absence of feudalism which would have led to representation by three estates in the core-lands of the Carolingian Empire ${ }^{26}$. This theory has been refuted on both theoretical and empirical ground $\mathrm{s}^{27}$. On the other hand, Hintze rightly pointed out that privileged immunity and the reciprocity of feudal obligations stand out as key concepts for the interpretation of the emergence of the right of resistance against arbitrary rule. His observation that centralised state power was a prerequisite for the formation of political representation on a territorial basis could be substantiated e contrario, namely its absence in regions dominated by what he called "municipal structures" (as in North and Central Italy) or by feudal rivalries (as in Poland since the late sixteenth century). The latter case is less convincing than the former since the combination of a bicameral central parliament (Sejm) with provincial assemblies (Sejmiki) had developed before the degradation of monarchical power in the late sixteenth century, and continued to function, albeit with weak powers and being limited to the order of the nobility (that included about nine percent of the population).

Hintze pointed to yet another necessary condition for the emergence of representative assemblies in the monarchs' search for support by citizens leading to the inclusion of the "Third Estate". This point is crucial indeed and can be elaborated further, especially as cities combined the ecclesiastical concept of personal and collective immunity with the feudal bilateral model of negotiated privilege and self-defence ${ }^{28}$.

Cities embodied unprecedented numbers of people and were the central places of the growing commercialised economy which generated mobile capital. The accumulation of capital provided impressive means of power in the hands of the urban merchant elites. Depending on the size of cities and their density within a particular territory, their concentrated wealth could make them an unavoidable, or even a dominant factor in the regional balance of powers. The local elites organised themselves protection of their trade over long distances which transgressed territorial boundaries. In doing so, they introduced the

${ }^{26}$ Hintze O. Typologie der ständischen Verfassungen des Abendlandes // Historische Zeitschrift. 1930. Bd. 141. S. 229-248; reprinted in: Hintze O. Gesammelte Abhandlungen I. Staat und Verfassung. Göttingen, 1970. S. 84-119.

27 Moraw P. Zu Stand und Perspektiven der Ständeforschung im spätmittelalterlichen Reich // Die Anfänge der ständischen Vertretungen in Preußen und seine Nachbarländern / Hrsg. H. Boockmann. Munich, 1992. S.5-6; Blockmans W. A typology of representative institutions in late medieval Europe // Journal of Medieval History. 1978. Vol. 4. P. 189-215.

28 Peter Spufford made this point: Spufford P. Origins of the English Parliament. London, 1967. P. 11-14. 
notion of economic policy in the public domain, which was far from the sphere of interest of the traditional princely courts. Additionally, around 1300, a new type of warfare by large units of bowmen and infantry - organised in the urban craft guilds and militias challenged the traditional supremacy of the heavily-mounted chivalry; as a consequence, the aristocracy's supremacy of physical power could not be maintained in the urbanised regions.

In contrast to Hintze's bold statement, urban governments were very well capable of organizing themselves on the scale of their own economic activities. In the twelfth and thirteenth centuries, various interurban merchants' organisations called hansa secured trade relations on particular interregional routes, a task gradually shared with territorial rulers and continuously monitored by urban administrations ${ }^{29}$. The German Hanse was the largest and longest lasting case of a nearly unique urban association aiming at the collective protection of their members' economic interests. Its regional and general assemblies (Hansetag) were composed by representatives of the urban governments. The membership of the chivalric Teutonic Order, active in Prussia, implied a non-municipal element of clerical landlords autocratically ruled by the grand-master. In an article published in 1978, I argued that it was the regions with the highest urban density in Europe that showed the highest representative activity. Urban representatives were the most noticeable participants, and economic affairs, including conflict settlement in maritime trade, featured prominently on their agenda ${ }^{30}$. On this basis, Hintze's statement that "municipal structures everywhere excluded representation by estates" has to be corrected in two ways: first, as argued above, clergy and aristocracy generally did not represent any political community, and second, urban governments, who did represent their communities, proved to be the most active and characteristic component of territorial representative institutions, in various forms. Metropolises, however, would dominate wherever other powers did not counterbalance them.

It should not come as a surprise that the social basis of political decision-making in principalities broadened from the twelfth century onwards. Population had grown over two centuries, and rural surpluses became concentrated in cities. It is well-known that this process was characterised by significant regional variation in timing and intensity. The demographic growth was made possible thanks to the increased level of pacification - the end of massive invasions as well as the internal peace movement launched by the reforming Catholic Church - which facilitated the intensification of agricultural production and the expansion of trade relations. The maritime trade across the Mediterranean fostered the transfer of practices, knowledge and products from the higher developed regions in the Near East to Italy and the other western coastal areas. Urban centres took advantage of the initial weakness of monarchical power to establish a high degree of autonomy, mimicking the movement launched by the popes since the mid-eleventh century under the motto of "liberty" from interference by lay lords. In line with the preceding observation that neither

29 Blockmans W.: 1) The Medieval Roots of the Constitution of the United Provinces // The Medieval Low Countries. 2017. Vol.4. P.219-223; 2) Public Authorities and Private Interests in Flanders in the $12^{\text {th }}$ to the $15^{\text {th }}$ centuries $/ /$ Entrepreneurs, Institutions and Government Intervention in Europe $\left(13^{\text {th }}-20^{\text {th }}\right.$ centuries). Essays in honour of Erik Aerts / eds B. Dewilde, J. Poukens. Brussels, 2018. P. 53-64.

30 Blockmans W. 1) A typology of representative institutions in late medieval Europe; 2) Lordre du jour politique des assemblées représentatives des Pays-Bas aux XIVe et XVe siècles // Pour la singuliere affection qu'avons a luy. Etudes bourguignonnes offertes à Jean-Marie Cauchies / eds P. Delsalle, G. Docquier, A. Marchandisse, B. Schnerb. Turnhout, 2017. P. 25-41. 
the clergy nor the nobility (with the exception of the English knights of the shire) can be seen as representatives of any political community, I start from the assumption that there was only popular representation when citizens, and possibly also rural communities, participated in territorial decision-making via delegates accountable to those collectives who had given them a mandate. Originally, that may have been assemblies of all male citizens; in the larger cities, common councils of a few hundred people recruited from the patriciate, guilds and crafts remained active, albeit in a decreasing number of cities between 1500 and $1700^{31}$. I will now discuss three (clusters of) regions characterised by a relatively high degree of urbanisation and commercialisation to check which other factors favoured representation, and in which form. First comes northern and central Italy, second - Flanders, and third - Languedoc, Catalonia and Aragon. Only in the latter cluster, assemblies of Estates were established at an early stage, in Flanders the largest cities spontaneously developed an independent consortium, while the metropolises in northern and central Italy dominated their hinterland.

Lombardy and Tuscany formally belonged to the authority of the Roman Emperor, but sheer logistical reasons of distance and cultural difference explain why emperors simply lacked the means of power to control developments south of the Alps. These relations became strained at the moment when ambitious emperors saw the attractions of the new riches in the Italian cities. Frederick I (1152-1190) tried to recuperate regal rights in Lombardy which had been alienated for centuries, and played smaller towns off Milanese expansionism by granting them privileges. Thanks to their collaboration, he collected the means to subdue Milan by military power in 1162 . This demonstration encouraged four cities located eastward in the Po valley to form a defensive league against the emperor's threat, which movement rapidly grew by the accession of Milan and a number of its surrounding towns, as well as some larger cities in the Emilia region. Their military alliance was accompanied by "parliaments" between representatives of the member-cities who negotiated agreements about their mutual relations, common military actions, and their financing. In 1183, this "Lombard league" succeeded in defeating the imperial army and securing their autonomy and recognition of their rights. The League was renewed time and again to organize the resistance against Emperors Henry VI and Frederick II ${ }^{32}$. From 1225 onwards, the external threat diminished, which reoriented the strife for urban autonomy towards the expansion of the cities' control over the countryside. The first targets were the bishops who had wielded worldly power over the territory of their bishopric, the contado; then came the lay landlords; all of them had to be bought or fought out, or were lured into integratation with the urban elites. The cities needed to secure the provisioning of their population with food and raw materials, and therefore aimed at controlling vital roads and water-courses. This process revitalised the competition between the cities themselves, whose strife resulted in the pattern of regional hierarchisation and finally - in the domination of regions by the largest metropolises ${ }^{33}$. Mixed urban elites were comprised of great merchants owning landed property and former landlords. Noblemen made up five to six percent of the population of important cities such as Florence, Piacenza and Perugia.

31 Prak M. Citizens without Nations. P. 63-82.

32 Raccagni G. The Lombard League 1167-1225. Oxford, 2010.

33 Jones P. The Italian City-State. From Commune to Signoria. Oxford, 1997. P. 270-321; Wickham C. Sleepwalking into a New World. The Emergence of Italian City Communes in the Twelfth Century. Princeton, 2015. 
These elites expanded and intensified their grasp on the countryside as well as on smaller towns. In the fourteenth and the first half of the fifteenth centuries, northern and central Italy fell into harsh warfare lasting until a peace was concluded in 1454 which stabilised the regional states. The dominant cities were twice as populous as those standing next to them in the urban hierarchy ${ }^{34}$ and they concentrated a disproportionally high share of the wealth in the region. Florence, for example, housed 14 percent of the state's population but they owned two-thirds of the land and 78 percent of the total wealth ${ }^{35}$. Dominant cities generally tried to impose their supremacy by bilateral negotiation or jurisdiction, and they left self-governance and law of the local communities largely intact. However, none of the metropolises allowed the subaltern administrators to assemble all together to formulate their grievances and to discuss fiscal and political issues. Subjects and communities were entitled to submit petitions and supplications claiming redress of alleged violations of the Capitoli di Dedizione, the "Articles of Dedication / Surrender". When Venice submitted the Patriarchate of Aquileia in 1420, it did not immediately abolish the Parliament that had functioned there since the thirteenth century. The aristocracy and the unfree chivalry (ministeriales) largely outweighed the two other Estates. However, Venice preferred instead to deal with a small number of self-appointed delegates with regard to taxation and separately - with the representatives of the capital city Udine. The role of the Parliament became purely ceremonial ${ }^{36}$.

Helmut Koenigsberger explained why the highest developed region of medieval Europe did not allow any form of political participation on the territorial level: "It could never be in the interest of Florence to summon the representatives of Tuscan cities together and thus give them a chance to co-operate against herself" 37 . The main differences between the regional capital cities and the imperial endeavours to dominate Lombardy and Tuscany, from Frederick I to Henry VII (1309-1313), were that the urban magistrates knew how to deal with their fellow-citizens, respecting treaties, local customary law and the wish for self-government; they did not impose foreign rulers or reintroduce outdated impositions, nor did they destroy the insubordinate cities, as Frederick I did in Milan in 1162. The cities did organize regular "parliaments" during the years 1168 to 1225 to coordinate their resistance against imperial assaults on their acquired freedom. Collectively, they successfully opposed monarchical supremacy. As soon as the external challenge faded away, internal competition turned into the advantage for the biggest contenders, in the same way as it happened among feudal lords.

Dynastic hazards triggered fundamental developments in political systems. The county of Flanders experienced a spectacular clash between the unruly chivalric use of violence and the needs of an urbanised society. Urban expansion had been considerable during the eleventh century, and the region thrived thanks to large-scale textile production of its trade over long distances. The oldest known urban charter dates from before 1111. In 1127, the count was murdered in the context of feuding clans of free and unfree and knights (ministeriales). In that power vacuum, the contest for two successions of the

34 Pinto G. Poids démographique et réseaux urbains en Italie entre le XIIIe et le XVe siècle // Villes de Flandre et d'Italie / eds E. Crouzet-Pavan, E. Lecuppre-Desjardin. Turnhout, 2008. P. 13-14.

${ }^{35}$ Herlihy D., Klapisch-Zuber C. Tuscans and their families. A Study of the Florentine catasto of 1427. New Haven; London, 1985. P. 94.

${ }^{36}$ Marongiu A. L'Istituto Parlamentare in Italia dalle origini al 1500. Rome, 1949. P. 134-139, 176-182.

37 Koenigsberger $H$. The Italian Parliaments from their Origins to the End of the $18^{\text {th }}$ Century // Politicians and Virtuosi. Essays in Early Modern History. London, 1986. P. 32-33. 
count in 1127 and 1128 offered great opportunities for the citizens to extend their liberties and to see them confirmed in formal charters. Competing candidates easily granted what was submitted to them in order to gain support. The citizens of Bruges gathered in a general assembly on a large open space where they swore to elect a suitable person count; numerous aldermen, good and strong citizens from the surrounding towns came to join by their oaths on the relics of the saints. Legislative autonomy was top of the list, with the abolition of feudal duties. The new Count William of Normandy granted the right of the aldermen to uphold the city's law, even against his own person. Moreover, he promised to protect the sworn commune ${ }^{38}$. Chronicler Galbert of Bruges quotes another candidate, the prospective count Thierry of Alsace, who presented himself in a letter sent to the assembled barons and citizens in March 1127 allegedly in those terms: "I will be just, peaceable, amenable and will provide for what is commonly useful and the common welfare" ${ }^{39}$. The choice of these expressions clearly pointed to the lively sense of communal interests superseding the aristocratic rivalries.

Count William of Normandy, whom King Louis VII of France appointed, soon provoked urban rebellions by disturbing the peace of the market in Lille and by imposing a viscount in Saint-Omer of whom the citizens said that he "had plundered the citizens' possessions and goods by force and continued to do all he could to pillage them" ${ }^{30}$. In February 1128, the citizens of Ghent rose in rebellion against their castellan for similar reasons. Together with the barons of the county, they called the count to render account of all the breaches of the oaths he had sworn and the privileges he had granted on the occasion of his accession to the throne. Galbert reports a speech by one of the barons, Ivan, in which he publicly accused the count on behalf of the citizens in these remarkable words:

"Lord count, if you had wanted to deal rightfully with our citizens and your burghers and us [the barons] their friends, you would not have inflicted perverse demands for money and assaults on us, but would rather have defended us from enemies and dealt honourably with us. Now, however, you have in your own person, despite law and the sacraments, broken the oaths we [the barons] swore on your behalf concerning freedom from having to pay the toll, the strengthening of the peace, and other judicial decisions granted to men of this land by your predecessors $\langle\ldots\rangle$ and by you, and you have violated your faith and ours, which we swore together in this matter along with you. $<\ldots>$ Let your court meet, if you please, meet in Ypres, which place is in the middle of your land, and let the leaders from both sides and your fellow peers and all the wiser men from among the clergy and people come together in peace and without arms, dispassionately and most attentively, without scheming or bad intention, and decide. $<\ldots>$ If you are lawless, faithless, deceitful, and an oath-breaker, give up the county and hand it over to us to entrust it to some able and lawful man"41.

This speech is of an extraordinary rhetorical quality, making use of concepts with subtlety and current political ideas which had been circulating in the context of the investiture contest. It expresses the fundamental principles of the rule of law in the context of a constitutional monarchy, including the right of impeachment controlled by an assembly

38 Actes des comtes de Flandre, 1071-1128 / ed. by F. Vercauteren. Bruxelles, 1938. Nr. 127. P. 293-299.

39 Galbert of Bruges. The Murder, Betrayal, and Slaughter of the Glorious Charles, Count of Flanders / ed. by J. Rider. New Haven; London, 2013. P. 82.

40 Ibid. P. 147-148.

${ }^{41}$ Ibid. P. 149-150. 
composed by the count's council, enlarged by representatives of the three Estates. No earlier and more precise description is known in European history of this institutional setting in a real political context. As the count rejected the argument and mobilized an armed force to break the opposition, the proposed procedure did not come into effect. However, he lost his life in the fighting, and the newly elected count Thierry of Alsace reconfirmed and extended the privilege for Saint-Omer (and probably also for the other cities), adding a special guarantee by nine barons, among whom was Ivan who delivered the speech in Ghent $^{42}$. This extension of the baron's right for resistance as the count's vassals to guaranteeing the rule of urban law under the jurisdiction of the city's aldermen meant nothing less than the transfer of a principle of feudal law to public law.

After these turbulent years, the relations between the counts and their major cities seem to have stabilized for several decades. The events remained well-stored in the collective memory, and references to this dramatic precedent were made in later centuries. The meeting of an assembly of the three Estates to decide about the count's impeachment, projected in 1128, never materialized. It would last until 1385 before Duke Philip of Burgundy, count of Flanders, summoned the very first assembly of Three Estates in Flanders. In the thirteenth and fourteenth centuries, however, the main cities, and occasionally also smaller towns and rural districts frequently met, on their own initiative or on the count's, to deal with all kinds of topics with the count and his councilors, with foreign authorities, and among themselves. They remained the most active element in the county's representative institutions until the end of the Ancien Régime ${ }^{43}$.

In Languedoc, Catalonia, and Aragon urban growth underwent impulses from Mediterranean trade, but the cities' size and density did not reach either the Italian or the Flemish levels. It was the bishops who, towards the end of the tenth century, launched the movement to secure the protection of peasants and travellers against the chivalric violence. In the south, however, feudal relations were less tightly bound to monarchical power than in the north, leaving the landlords in a fairly autonomous position. In 1155, King Louis VII of France took the lead in the movement to coerce the barons of Languedoc to swear an oath to respect the peace, initially launched by bishops. King Ramon Berenguer III of Aragon (1144-1166) promulgated, after consultations with representatives of six cities, that peace-breakers would be judged in special episcopal or royal courts. In 1173, his successor Alphonse I and the bishops in "all his Catalan realms" issued a prescription to all aristocrats to swear an oath to keep the peace. It was witnessed by thirteen barons, "in the common interest of all the lands", but the spiritual sanctions didn't impress most of the barons. In 1198, King Peter I of Aragon had to concede not to support any subject against his lord and not to set up a peace-making army; moreover, he had to recognize the lords' right to maltreat their serfs (ius maltractandi) ${ }^{44}$.

In the same period, a common court of some noblemen and representatives (the "good men") of towns and villages in the region of Agen, in southwestern France, settled disputes that might threaten the peace; that court was entitled to mobilise a common

${ }^{42}$ De oorkonden der graven van Vlaanderen (juli 1128 - september 1191) / door T. de Hemptinne en A. Verhulst. Vol. II/1. Bruxelles, 1988. P. 17.

43 Prevenier W. Les Etats de Flandre depuis les origines jusqu'en 1790 // Standen en Landen - Anciens Pays et Assemblées d'Etats, 1965. Vol. XXXIII. P. 15-59.

${ }_{44}$ Bisson T. The Crisis of the Twelfth Century. Power, Lordship, and the Origins of European Government. Princeton, 2009. P. 499-514, 531. 
militia to enforce the public order. Thomas Bisson qualified such assemblies of common men from rural and urban communities as the "earliest experiences before 1200 of assemblies of estates representing the land". They issued edicts applicable to a whole territory in Quercy, Aragon, and Catalonia. By linking local communities, they created a public political identity ${ }^{45}$. In each of these regions, representative institutions acquired substantial power in the thirteenth and fourteenth centuries, and they maintained political leverage in Aragon until the Bourbon repression in 1713, and in Languedoc - until the Revolution.

In each of the three regional clusters discussed above, the emergence of an urbanised and commercialised society was the crucial incentive to the enlargement of the political system. New needs became crucial; they were focused on security in the public space, and the trading routes in particular. Stability of the coinage was another issue of great concern for the subjects who tried to set terms to the monarchical regal right in this domain. Northern and Central Italy featured the highest concentration of conflicting powers: that of the emperor against the largest and most concentrated cities in Roman-Catholic Europe. Flanders also had a dense urban network, but its towns were smaller than the Italian ones, and the divergence between the largest ones and the second level in the hierarchy was less outspoken. On the monarchical side, the King of France did not intervene militarily in Flanders before 1300, and the position of the count was weakened by the competition between various foreign candidates. The major cities grasped the opportunity to secure their own interests in a common consortium as the powers were balanced between themselves as well as between the cities and the count. In the third cluster, the urban network was smaller in population and less dense than in the Italian and Flemish cases; the rulers' position was primarily challenged by the barons, which made a coalition of the crown with bishops, citizens and villagers obvious.

A basic structural precondition for broadening political participation through the inclusion of rising social classes was that none of them, even the monarchical government, was in control of a clear preponderance in the means of power. It was the balance of powers which made negotiations with the new social classes of citizens and free peasants necessary. Concretely, the great cities controlled more concentrated capital than any other contender for power in the region. Moreover, their strategic location provided them with leverage on the whole hinterland's welfare. For that reason, Florence could not suffice to thrive on its strategic location on the overland routes: in its competition with the surrounding powers it needed to subdue its natural out-port Pisa, and later on - Livorno. The incorporation of the landed aristocracy into the elite of the major cities coupled with the land-investment of the urban merchant class, prevented a structural opposition between the aristocratic and bourgeois estates. The dominant cities in northern and central Italy determined the power relations within their regional states and far beyond them in their intercontinental trade networks. Given their overwhelming supremacy, they did not need to negotiate with the collective of subdued cities, towns, and rural communities.

In Flanders, the major cities did not have a comparable preponderance vis-à-vis the smaller ones, and the aristocracy continued to play its role within a gradually pacified juridical and administrative framework. The mercantile elites organised and protected their commercial networks on a trans-territorial scale. As the urban governments were recruited among their families, they felt the freedom to protect their trading interests also

${ }^{45}$ Bisson T. Assemblies and Representation in Languedoc. P. 73-93, 102-132. 
through an informal association of the major cities, when needed - in collaboration with the count. It is on that basis that during the recurrent crises of monarchical power during the fourteenth century, the three largest cities tended to impose their control over their hinterlands. Since 1385, the strong counts of the Burgundian dynasty tried to curb the great cities' hegemony. Only then did the count introduce top-down the format of assemblies of Three Estates, which, however, never prevailed over the cities' lasting power. These tensions lasted and peaked in the revolt against Spanish rule from the 1560s onwards.

The third cluster was the only one (also in Europe as a whole) where assemblies of three Estates (in some cases - four, differentiating barons and chivalry) emerged during the late twelfth century. Social and economic developments were balanced between social classes which pursued different, and partially opposed interests that were vested in distinct sectors of the economy. The relatively low density of the urban settlements - most of which were located along the coast - explains the ongoing dominance of the greater landlords. Only a coalition of the king, the bishops, the cities and rural communities could try to pacify the country and to create monetary stability. Barcelona was the main metropolis whose merchant class used the negotiations with the crown to expand its maritime empire, in the same way as the Aragonese aristocracy supported the king's expansionist Reconquista in the kingdom of Valencia. Political participation is also a way to serve private interests.

As a conclusion for this section, it has to be observed that the development of urbanization and commercialisation was a necessary condition for the emergence of representative institutions, but not a sufficient one. Popular political participation emerged and survived only in situations in which countervailing powers kept each other in balance. The inclusion of larger layers of society in political decision-making was part of the emancipatory trend which followed the inter-secular growth. Emancipated citizens and peasants sought to pursue their own goals and interests, which required their political activity. Instability of the monarchy triggered participation from "below" though it did not by itself warrant its stabilisation. Any powerholder that sees an opportunity for hegemony will grasp it: feudal lords and monarchs just as well as dominant cities.

Consolidation and Challenge. Monarchs generally held to themselves the decision when to summon and to dissolve parliamentary meetings, and to determine their agenda. Attempts to agree on regular time schedules rarely materialised. In England, Edward I in 1275 promised two sessions per year, which he respected only if the meetings of just the clergy and barons are taken into account; long periods of crisis disrupted this schedule in 1307-1327, 1376-1390, and 1449-1483 ${ }^{46}$. In Aragon, a yearly session was agreed upon in 1283, but no Corts were held at all between 1292 and 1300; the king then unilaterally decided to summon one meeting every three years, changed it into a two-year frequency, which did not introduce any regularity ${ }^{47}$. The States General of the Low Countries stipulated the right of spontaneous assemblies in 1477, which never materialised; in 1488, they concurred that an annual session should be held to hear the grievances, which never became a regular practice ${ }^{48}$. Ultimately, problems of dynastic continuity and the crown's military and financial needs determined the summoning of the assemblies, as well as their duration.

46 Maddicott J.R. The Origins of the English Parliaments, 924-1327. Oxford, 2010. P.300-311.

47 Bisson T. The Medieval Crown of Aragon. Oxford, 1986. P. 64-67, 80-81, 88-90.

48 Blockmans W. Medieval Roots. P. 245. 
Unions of cities were entitled to meet on their own initiative, which they did in Flanders in 1127-1128, and, more regularly, from the thirteenth century until the end of the Ancien Régime. Since around 1300, major cities in neighbouring Brabant and Holland developed a similar pattern, albeit in a less polarised hierarchy. The regional unions of the mercantile elites in northern Germany consolidated in the course of the first half of the fifteenth century in the German Hanse, grouping around two-hundred cities. In their essence, this pattern differed from the other urban unions only with regard to the fact that their trade routes on the Baltic and North Seas shaped a stronger common interest than many different and relatively weak monarchical authorities to which they resorted ${ }^{49}$. Similarly, the urban elites in the Low Countries felt free to negotiate with their trading partners in the Hanse, in England and along the North Sea and Atlantic coasts as far southward as Iberia, unhampered by their dynastic belonging. The constitutionalist tradition in the research on representative institutions disregarded this functional equivalence, but, in practical terms, the frequent regional and general meetings and the intensive diplomatic activities deployed by the Hanse dealt with economic policy, trade relations and conflict management in exactly the same way as the associated urban governments did in the Low Countries or Catalonia. Depending on the geographical characteristics, the special position of single central places such as Paris, London and Lisbon could be effectuated by direct links between the court and the local merchant elite ${ }^{50}$.

Rostock and Wismar belonged to the Wendic cities that since 1259 had united with Lübeck and others to protect their maritime trade, and that would form the core group in the German Hanse one century later. They regularly held meetings to settle their trading disputes. In that light, it is easy to understand how during ducal successions to minors in the duchy of Mecklenburg in 1282 and 1329, these two cities succeeded in forming regency councils in conjunction with members of the aristocracy ${ }^{51}$. In the lands of the Crown of Castile, hermandades (confraternities) of cities met frequently in the years of instability of the Crown between 1281 and 1329. They claimed control of the finances and the chancery, submitted cuadernos, lists of grievances, and pressured rivalling pretenders to the throne to grant privileges. Up to 180 royal cities were involved, of which 78 were located in the kingdom of Castile, 45 in León, and the others in adjacent territories. Once King Alfonso XI (1329-1348) was well established on the throne, he didn't summon any general Cortes, and the hermandades fell apart ${ }^{52}$. The territory's great extension and the relatively low density of the urban population hampered regular consultations. In the process of the Reconquista, the Catholic kings had founded cities as strongholds to control vast surrounding countryside. With a few exceptions such as Burgos, the urban elites were not primarily involved in trade, but were landholding hidalgos, enjoying a chivalric status and lifestyle. This oligarchic model helps to understand how since 1538, the Cortes could be reduced to

49 The Hanse in Medieval and Early Modern Europe / eds J. Wubs-Mrozewicz, S. Jenks. Leiden, 2013.

50 Rawcliffe C., Clark L. Introduction // Parliament and Communities in the Middle Ages / eds C. Rawcliffe, L.Clark // Parliamentary History. 1990. Vol. 9. P.233-242; Aguiar Andrade A., Miranda F. Lisbon: Trade, urban power and the king's visible hand // The Routledge Handbook of Maritime Trade Around Europe 1300-1600 / eds W. Blockmans, M. Krom, J. Wubs-Mrozewicz. London, 2017. P.339-342.

${ }^{51}$ Engel E. Frühe ständische Aktivitäten des Städtebürgertums im Reich und in den Territorien bis zur Mitte des 14. Jahrhunderts // Städte und Ständestaat. Zur Rolle der Städte bei der Entwicklung der Ständeverfassung in Europäischen Staaten vom 13. bis zum 15. Jahrhundert / Hrsg. B. Töpfer. Berlin, 1980. S. 46, 53.

52 O'Callaghan J. F. The Cortes of Castile-León 1188-1350. Philadelphia, 1989. P.79-93. 
18 cities without the clergy and the high nobility, while the deals on the taxes were made in bilateral negotiations ${ }^{53}$.

If high levels of urbanization and commercialisation were a precondition for the incorporation of new elites in representative institutions, it follows that this emancipatory drive, in some cases including the "Alleingang" (going it alone) of clusters of major cities, was weaker or even absent in the predominantly rural areas in North, Central and East Europe. An interesting case is that of the cities along the lower Vistula, from Danzig (Gdansk) and Elbing (Elblag) to Thorn (Torun), colonised by the Teutonic Order and after 1466 gradually incorporated into the Kingdom of Poland. The whole region thrived on grain export to the West, the cities as well as the Order belonged to the Hanse, and they developed a remarkably active representative activity, largely focused on economic poli$\mathrm{cy}^{54}$. In general, however, the urban density, the population of the largest cities, and the level of capital accumulation were significantly lower in Central, Northern and Eastern Europe than in Northern and Central Italy and in Western Europe. Nevertheless, major cities fulfilled central market functions for extended regions. Some of them, such as Leipzig, were crucial nodal points thanks to their international fairs ${ }^{55}$.

Merchants from Brabant were arrested abroad and their goods confiscated as retaliation for the duke's accumulated debts, which prompted the cities in 1293 to unite and urge the duke, in return for their financial aid, to grant them a series of privileges, including the right of passive resistance if he violated his commitments. As the situation had not improved by 1312, the cities took the lead of a regency council that kept control of the duchy's finances and administration until 1320. The right of refusal of service and obedience in the case of infringement of rights was to be monitored by a standing committee of the estates. The latter would soon be sidelined, however, as soon as the new duke was fully established in his powers ${ }^{56}$. Nevertheless, the subjects' right of resistance was confirmed and even extended to the individual level, in general - in the charters for the Low Countries of 1477 and 1488, and put into practice with the deposition of King Philip II in $1581^{57}$.

On the whole, the idea of attracting both the financial expertise and the capital from the commercialising economy, inspired many rulers in continental Europe to include the merchant elite in the orbit of their consultations. During the fourteenth and fifteenth centuries, the rapidly increasing financial needs of wars brought about frequent meetings of the English Parliament and the French States General and regional Estates, introducing new and lasting forms of direct taxation of citizens and peasants. A financial crisis prompted the Estates of Bavaria in 1356 to erect a committee drawn from their midst, to levy taxes, participate in the election of councillors and in the legislation, and to hear

${ }^{53}$ Fortea Pérez J. I. Las Cortes de Castilla y León. P. 85-121.

54 Neitmann K. Die Landesordnungen des Deutschen Ordens in Preußen im Spannungsfeld zwischen Landesherrschaft und Ständen // Die Anfänge der ständischen Vertretungen in Preußen und seine Nachbarländern / Hrsg. H. Boockmann. Munich, 1992. S. 59-81; Biskup M. Die Stände in Preußen Königlichen Anteils 1466-1526 // Die Anfänge der ständischen Vertretungen... P. 83-99.

55 Denzel M. Das System der Messen in Europa - Rückgrat des Handels, des Zahlungsverkehrs und der Kommunikation // Europäische Messegeschichte 9.-19. Jahrhundert / Hrsg. M. Denzel. Cologne, 2018. S. 384-402.

56 Van Uytven R., Blockmans W. Constitutions and their application in the Netherlands during the Middle Ages // Revue belge de Philologie et d'Histoire. 1969. Vol. 47. P. 399-424.

57 Blockmans W. Medieval Roots. P. 237-248. 
grievances. Dynastic problems had already led to the formation of a union between nobles and cities (Einung) to decide on all political matters in 1315 and $1324^{58}$.

In Central, Nordic and Eastern Europe, the political impact of cities remained exceptional and mostly limited to critical situations of the dynasty or the finances. The wealth remained overwhelmingly in the hands of the aristocracy and their relatives in the higher clergy. Only the old capital city Cracow held a seat in the Polish Sejm, and for that reason it was considered to enjoy a noble status. Since the incorporation of Western Prussia in 1466, the three main cities Danzig, Elbing and Thorn were admitted to the Sejm, but were excluded in 1569. When the Union of Poland and Lithuania was concluded, a large number of Lithuanian noblemen were included in addition to representatives of Vilnius, were ennobled just for that occasion.

The formation of truly representative institutions, which I define as those including a decisive section of mandate holders on behalf of urban and (in some regions such as Tirol and Flanders also) rural communities, can be linked with the demographic and economic growth that led to urbanisation and commercialisation. The timing and the level of this transformation varied significantly between European regions. In Jan de Vries' computation based on population estimates around 1500, the "urban potential" varied from a factor 80 in Northern Italy, Naples and its surroundings, and the Southern Low Countries; 50 - along the Ligurian coast and the Rhône valley, Northern France, London and the southeast of England, and all the Low Countries; 30 - in the rest of England and central Germany; and below that level in Iberia, Scandinavia north of Seeland, and Central Europe East of the Elbe and Trieste ${ }^{59}$. This significant variation evidently found its expression in the social structures of the societies, and thus in the potential of citizens and free peasants to push for their emancipation, civil rights, and political participation. In the fourteenth century, the growth of the preceding centuries turned into a dramatic decline, with the loss of around one-third of the European population as a whole. Correspondingly, the emancipatory drive slowed down, and those who had obtained privileges now fought for their maintenance, even the members of the craft guilds in the largest cities. This trend was reinforced by the general tendency of institutions towards inertia and oligarchisation.

The late fifteenth and sixteenth centuries were characterised by a gradual recovery of the demographic and economic evolutions, especially in north-western Europe. Only in some countries did this correspond with a renewed dynamism of the representative institutions, especially in England, the Low Countries, and Sweden. Elsewhere and in the long term, however, the overall tendency was to their decline, as it can be shown in the activity of the Catalan Corts. The yearly average of their meetings peaked in 1406-1458 on 172 days, slowing down to 91 in $1468-1515$, and to 20 in $1519-1599^{60}$. Two factors stand out to explain the nearly general decline of representative activity in the sixteenth to eighteenth centuries. The first was that rulers strongly held on their prerogative to wage war, which they legitimated by the honour and common interest of the country; the second was that the Reformation provided rulers with a motive for extreme repression. Emanci-

${ }^{58}$ Engel E. Frühe ständische Aktivitäten... P. 32-33.

59 De Vries J. European Urbanization 1500-1800. London, 1984. P. 160. - The figures are percentages, as related to the largest city in the most densely urbanised area around 1500, Venice.

${ }^{60}$ Conde R., Hernández A., Riera S. \& Rovira M. Fonts per l'estudi de les Corts: els Parlaments de Catalunya. Catàleg dels processos de Corts i Parlaments // Les Corts a Catalunya. Actas del Congrès d'Història Institucional. Barcelona, 1991. P. 25-61. 
patory movements such as that of the Hussites in Bohemia, the peasants in southwestern Germany, or the new artisanal and mercantile classes in the Low Countries, were inspired by the religious controversy. Monarchs strengthened their position by imposing a single state church, for which they applied all means of coercion. In the light of these new challenges, rulers referred to the notion that "necessity breaks law" (necessitas non habet legem), frequently repeated in canon law texts since the twelfth century, which then passed to civil law, theology and political philosophy. French kings referred to the "great necessity" in their summons to the general assemblies in the fourteenth century. In 1359, the Estates of Provence protested against the false pretence of necessity to levy troops without real justification ${ }^{61}$. Rare endeavours of representative institutions to obtain the decisive voice in declaring and ending wars themselves, were systematically denied by kings who bluntly confronted the subjects with the accomplished facts against which the parliaments couldn't react adequately. Indeed, once a war had started, from whatever side, there was no way back, and subjects were obliged, and even prepared to defend their own territory, rather than to become victims of aggression.

Warfare was by far the states' highest single item of expenditure, and it rose dramatically in the sixteenth and seventeenth centuries. "As a general rule, the monarchical states devoted almost half of their budgets to military activity. $<\ldots>$ During the last decades of the seventeenth century Sicily spent 65 per cent of its total expenditure, France 76 per cent, Denmark 88 per cent and Austria 96 per cent, on war" 62 . The public debt rose spectacularly as a means to finance warfare, and this also created accomplished facts against which the representatives saw no remedy. In Castile and Naples, the debt service rose from 12 per cent of the budget around 1500 to between 30 and 45 per cent in 1559, in Württemberg - to more than 80 percent. The unlimited demand for immediate cash to pay the troops, for the fortifications, and for the artillery, drove the interest rate in the Habsburg empire up to 48.8 per cent in the 1550s. Private investors profited grossly from these loans, even though they lost part of their gains in the ensuing so-called state bankruptcies.

Though mercantile and civic interests in general pleaded for peace and security, their political representatives proved unable to counter the consequences of the proliferating dynastic competition. The early-modern states were war-machines, with strong financial administrations built up for that purpose. Representative institutions proved unable to halt this self-strengthening process. The tendency to institutional inertia played a role in the gradual incorporation of representative elites into the state organisation. Warfare had its advocates in their midst. The clergy had a long tradition of manifestly encouraging and legitimating religious wars. The nobility could hope for individual gains, while some sections of the mercantile and entrepreneurial class saw opportunities to make exceptional profits. State administrations became strengthened through the wars, while the Estates lost in the process.

The Dutch Republic, England and Sweden showed an opposite trend: the population and economies grew, and representative institutions played a determining role. The strong involvement of the emancipating bourgeoisie in representative politics supported their vital interests in maritime trade, especially in the province of Holland. Though they were involved in the wars, these were mostly fought on foreign territories or on the seas. The

${ }^{61}$ Hébert M. La voix du peuple. P. 137-140.

62 Körner M. Expenditure // Economic Systems and State Finance / ed. by R. Bonney. Oxford, 1995. P. 408-411, quote on 411 . 
losses in population and capital were by far higher in the continental countries where the troops "lived from the land".

In the United Kingdom, the system of representation by counties and boroughs rested on election and mandate. Commercial and maritime interests were strongly represented in Parliament. Admittedly, its fixity implied distortions. The electorate in boroughs varied between a dozen men and its thousand-fold, and twenty to thirty percent of them were represented by non-resident gentlemen. Due to deals between candidates, elections were held in a minority of the districts: in 1705 only in 110 of the 266 . Nevertheless, in the early eighteenth century, the electorate in England and Wales counted a total of 300000 adult men, or 23 per cent of that population. As the population grew, that share dropped to between 14 and 17 per cent towards the end of the century ${ }^{63}$. These percentages nevertheless were higher than those in the mid-nineteenth century, even after the great Reform of 1832. A similar observation was made with regard to the Dutch Republic in the seventeenth and eighteenth centuries, though precise figures cannot be produced. Urban governments certainly were plutocratic, and in the other provinces than Holland, the landed aristocracy still weighed heavily on policies. But a wide range of civic organisations such as guilds, neighbourhoods, and militias linked the ordinary subjects to the elite, social care was provided on a large scale, and the people's voice could be heard ${ }^{64}$. The Swedish monarchy played a decisive role in the country's aggressive policy and the military organisation of the state. It nevertheless succeeded in involving the estates in the political decisions, and in particular the communities of free peasants and miners.

The general demographic and economic growth of the late eighteenth and nineteenth centuries would raise new emancipatory waves to which the oligarchic political systems gave in very reluctantly, after many and bloody upheavals, and typically under the extreme pressure of wars. Civil rights and political participation were never given for free, but the emergence of representative institutions, and their subsequent effectiveness can now be interpreted in the light of successive emancipatory waves that followed from expansive trends. Conversely, the reduction of political participation occurred in situations of stagnation or decline.

\section{References}

Hart M. 't The Dutch Wars of Independence: Warfare and Commerce in the Netherlands 1570-1680. London, New York, Routledge, 2014, 232 p.

Aguiar Andrade A., Miranda F. Lisbon: Trade, urban power and the king's visible hand. The Routledge Handbook of Maritime Trade Around Europe 1300-1600. London, Taylor and Francis, 2017, pp. 333-351.

Biskup M. Die Stände in Preußen Königlichen Anteils 1466-1526. Die Anfänge der ständischen Vertretungen in Preußen und seine Nachbarländern. Munich, Oldenbourg, 1992, S. 83-99.

Bisson T. Assemblies and representation in Languedoc in the thirteenth century. Princeton, Princeton University Press, 1964, 380 p.

Bisson T. The Crisis of the Twelfth Century. Power, Lordship, and the Origins of European Government. Princeton, Princeton University Press, 2009, 720 p.

Bisson T. The Medieval Crown of Aragon. Oxford, Oxford University Press, 1986, 239 p.

Bisson T. The Problem of Medieval Parliamentarism: A Review of Work Published by the International Commission for the History of Representative and Parliamentary Institutions, 1936-2000. Parliaments, Estates, Representation, 2001, vol.21, pp.1-14.

${ }^{63}$ Harris B. House of Commons // A Short History of Parliament / ed. by C. Jones. Woodbridge, 2009. P. $183-184$.

${ }^{64}$ Prak M. Citizens without Nations. P. 202-206, 304. 
Blockmans W. A typology of representative institutions in late medieval Europe. Journal of Medieval History, 1978, no. 4, pp. 189-215.

Blockmans W. L'ordre du jour politique des assemblées représentatives des Pays-Bas aux XIVe et XVe siècles. Pour la singuliere affection quavons a luy. Etudes bourguignonnes offertes à Jean-Marie Cauchies. Turnhout, Brepols, 2017, pp. 25-41.

Blockmans W. Public Authorities and Private Interests in Flanders in the $12^{\text {th }}$ to the $15^{\text {th }}$ centuries. Entrepreneurs, Institutions and Government Intervention in Europe (1 $13^{\text {th }}-20^{\text {th }}$ centuries). Essays in honour of Erik Aerts. Brussels, Academic and Scientific Publishers, 2018, pp. 53-64.

Blockmans W. The Medieval Roots of the Constitution of the United Provinces. The Medieval Low Countries, 2017, vol. 4, pp. 215-248.

Brunner O. Land und Herrschaft. Grundfragen der territorialen Verfassungsgeschichte Österreichs im Mittelalter. Brno, R. M. Rohrer Verlag, 1942, 526 S.

Conde R., Hernández A., Riera S., Rovira M. Fonts per l'estudi de les Corts: els Parlaments de Catalunya. Catàleg dels processos de Corts i Parlaments. Les Corts a Catalunya. Actas del Congrès d'Història Institucional. Barcelona, Generalitat de Catalunya, Departament de Cultura, 1991, pp.25-61.

De Vries J. European Urbanization 1500-1800. London, Methuen Press, 1984, 398 p.

Denzel M. Das System der Messen in Europa - Rückgrat des Handels, des Zahlungsverkehrs und der Kommunikation. Europäische Messegeschichte 9.-19. Jahrhundert. Köln, [s. n.], 2018, S.369-431.

Engel E. Frühe ständische Aktivitäten des Städtebürgertums im Reich und in den Territorien bis zur Mitte des 14. Jahrhunderts. Städte und Ständestaat. Zur Rolle der Städte bei der Entwicklung der Ständeverfassung in Europäischen Staaten vom 13. bis zum 15. Jahrhundert. Berlin, Akademie-Verlag, 1980, S. 13-58.

Fortea Pérez J. I. Las Cortes de Castilla y León bajo las Austrias. Valladolid, Junta de Castilla y León, 2008, $384 \mathrm{p}$.

Graves M. A. R. The Parliaments of Early Modern Europe. London, Longman, 2001, 230 p.

Guenée B. L'Occident aux XIVe et XVe siècles. Les Etats. Paris, Presses universitaires de France, 1971, 339 p.

Harding A. Medieval Law and the Foundations of the State. Oxford, Oxford University Press, 2002, 410 p.

Harris B. House of Commons. A Short History of Parliament. Woodbridge, Boydell Press, 2009, pp. 183-184.

Hébert M. La voix du peuple. Une histoire des assemblées au Moyen Âge. Paris, PUF, 2018, 307 p.

Hébert M. Parlementer. Assemblées représentatives et échange politique en Europe occidentale à la fin du Moyen Age. Paris, De Boccard, 2014, 687 p.

Herlihy D., Klapisch-Zuber C. Tuscans and their families. A Study of the Florentine catasto of 1427. New Haven, London, Yale University Press, 1985, 404 p.

Hintze O. Typologie der ständischen Verfassungen des Abendlandes. Historische Zeitschrift, 1930, Bd. 141, S. 229-248.

Hintze O. Weltgeschichtliche Bedingungen der Representativverfassung. Historische Zeitschrift, 1931, Bd. 143, S. 1-47.

Jones P. The Italian City-State. From Commune to Signoria. Oxford, Clarendon Press 1997, 702 p.

Koenigsberger H. G. The Italian Parliaments from their Origins to the End of the $18^{\text {th }}$ Century. Politicians and Virtuosi. Essays in Early Modern History. Ed. H. G. Koenigsberger. London, The Hambledon Press, 1986, pp. 27-63.

Körner M. Expenditure. Economic Systems and State Finance. Oxford, Oxford Universiry Press, 1995, pp. 408-411.

Krüger K. Die Landständische Verfassung. Munich, Oldenbourg, 2010, 148 S.

Maddicott J.R. The Origins of the English Parliaments, 924-1327. Oxford, Oxford University Press, 2010, $544 \mathrm{p}$.

Maddison A. Contours of the World Economy, 1-2030 AD. Oxford, Oxford University Press, 2007, 418 p.

Mann M. The sources of social power. Vol. I. A history of power from the beginning to A. D. 1760. Cambridge, Cambridge University Press, 1986, 549 p.

Marongiu A. L'Istituto Parlamentare in Italia dalle origini al 1500. Rome, Senato della Repubblica, 1949, $326 \mathrm{p}$.

Marongiu A. Medieval Parliaments. A comparative study. London, Eyre and Spottiswoode Publ., 1968, 306 p.

Moore B. Injustice. The Social Bases of Obedience and Revolt. London, Palgrave Macmillan Publ., 1978, 540 p.

Moraw P. Zu Stand und Perspektiven der Ständeforschung im spätmittelalterlichen Reich. Die Anfänge der ständischen Vertretungen in Preußen und seine Nachbarländern. Munich, 1992, S. 1-33. 
Myers A. R. Parliaments and Estates in Europe to 1789. London, Thames \& Hudson Publ., 1975, 180 p.

Neitmann K. Die Landesordnungen des Deutschen Ordens in Preußen im Spannungsfeld zwischen Landesherrschaft und Ständen. Die Anfänge der ständischen Vertretungen in Preußen und seine Nachbarländern. Munich, Oldenbourg, 1992, S. 59-81.

O'Callaghan J. F. The Cortes of Castile-León 1188-1350. Philadelphia, University of Pennsylvania Press, 1989, $280 \mathrm{p}$.

Pinto G. Poids démographique et réseaux urbains en Italie entre le XIIIe et le XVe siècle. Villes de Flandre et d'Italie. Turnhout, Brepols, 2008, pp. 13-28.

Popitz H. Phenomena of Power. Authority, Domination, and Violence. New York, Columbia University Press, 2017, 240 p.

Prak M. Citizens without Nations. Urban Citizenship in Europe and the World c.1000-1789. Cambridge, Cambridge University Press, 2018, 423 p.

Raccagni G. The Lombard League 1167-1225. Oxford, Oxford University Press, 2010, 231 p.

Rawcliffe C., Clark L. Introduction to Parliament and Communities in the Middle Ages. Parliamentary History. 1990, vol.9, pp. 233-242.

Rowen H.H. The Union of Utrecht and the Articles of Confederation, the Batavian Constitution and the American Constitution, a double Parallel. Herrschaftsverträge, Wahlkapitulationen, Fundamentalgesetze. Göttingen, 1977, S. 281-293.

Skocpol T. States \& Social Revolutions. A Comparative Analysis of France, Russia, \& China. Cambridge, Cambridge University Press, 1979, 421 p.

Spufford P. Origins of the English Parliament. London, Longmans Publ., 1967, 221 p.

Stollberg-Rilinger B. Vormünder des Volkes? Konzepte landständischer Reprasentation in der Spätphase des Alten Reiches. Berlin, Duncker \& Humblot GmbH ,1999, 370 S.

Stollberg-Rilinger B. Was heisst landständische Repräsentation? Überlegungen zur argumentativen Verwendung eines politischen Begriffs. Zeitsprünge. Forschungen zur Frühen Neuzeit, 2000. Band 4, Heft 1-2, S. 120-135.

The Hanse in Medieval and Early Modern Europe. Leiden, Brill, 2013, 296 p.

Van Gelderen M. The Dutch Revolt. Cambridge, Cambridge University Press, 1993, 304 p.

Van Gelderen M. The Political Thought of the Dutch Revolt 1555-1590. Cambridge, Cambridge University Press, $1992.330 \mathrm{p}$.

Van Uytven R., Blockmans W. Constitutions and their application in the Netherlands during the Middle Ages, Revue belge de Philologie et d'Histoire. 1969, vol. 47, pp. 399-424.

Wickham C. Sleepwalking into a New World. The Emergence of Italian City Communes in the Twelfth Centu$r y$. Princeton, Princeton University Press, 2015, 320 p.

Статья поступила в редакцию 23 февраля 2020 г.

Рекомендована в печать 8 июня 2020 г.

Received: February 23, 2020

Accepted: June 8, 2020 